\title{
ASSOCIATION BETWEEN POLYMORPHISM IN THE PROMOTER REGION (G/C-915) OF PAX9 GENE AND THIRD MOLAR AGENESIS
}

Fabio José BIANCHI ${ }^{1}$, Tiago Franco de OLIVEIRA ${ }^{2}$, Cristiane Borges Pereira SAITO', Regina Célia Rocha PERES 3 , Sérgio Roberto Peres LINE ${ }^{4}$

\author{
1- DDS, MSc, Postgraduate student, Department of Morphology, Dental School of Piracicaba, State University of Campinas, Piracicaba, SP, \\ Brazil. \\ 2- Graduate student, Department of Morphology, Dental School of Piracicaba, State University of Campinas, Piracicaba, SP, Brazil. \\ 3- DDS, MSc, PhD, Assistant Professor, Department of Pediatric Dentistry, Dental School of Piracicaba, State University of Campinas, \\ Piracicaba, SP, Brazil. \\ 4- DDS, MSc, PhD, Chair Professor, Department of Morphology, Dental School of Piracicaba, State University of Campinas, Piracicaba, SP, \\ Brazil.
}

Corresponding address: Prof. Dr. Sergio R. P. Line - Faculdade de Odontologia de Piracicaba, UNICAMP - Avenida Limeira 901, Cx. Postal 51, 13414-903 Piracicaba, SP, Brasil - Phone: 5519 2106-5333 - e-mail: serglin@fop.unicamp.br or fabiojbianchi@yahoo.com.br

Received: January 18, 2007 - Modification: March 07, 2006 - Accepted: May 29, 2007

\begin{abstract}
$P$

urpose: Hypodontia is the congenital absence of one or more (up to six) permanent and/or deciduous teeth, being one of the most common alterations of the human dentition. Genetic polymorphisms are variations of DNA sequences occurring in a population. This study investigated whether G-915C single nucleotide polymorphism (SNPs) in the PAX9 gene promoter is associated with hypodontia in humans. Material and Methods: The polymorphism in region G/C-915 of PAX9 gene (NCBI ref SNP ID: rs 2073247) of 240 patients was analyzed, being 110 controls and 130 individuals with third molar agenesis. After DNA extraction, the region of interest was amplified by PCR technique using two different primers. The significance of the differences in observed frequencies of polymorphisms in both groups was assessed by odds-ratio and chi-squared test with $95 \%$ confidence interval. Results: Genotype CC was more frequent in patients with agenesis (11.5\%) compared to the control (1.8\%), while GG was more prevalent in the control group (39.1\%) compared to the individuals with agenesis $(26.2 \%)$. Conclusion: These data showed that the allele $\mathrm{C}$ could be associated with the third molar agenesis.
\end{abstract}

Uniterms: Hypodontia; PAX9 transcription factor; Tooth abnormalities; Genetic polymorphism.

\section{INTRODUCTION}

Hypodontia, the congenital absence of one or a few teeth, is one of the most common developmental alterations of human dentition. Hypodontia is not a serious public health problem, but it may cause masticatory (temporomandibular joint disorders) and speech dysfunctions and create esthetic problems with orthodontic and prosthetic impairments ${ }^{29}$. In the past few years, several growth and transcription factors have been shown to be expressed in developing teeth ${ }^{26}$. The direct participation of several genes in tooth development was demonstrated by the lack of teeth in mutant knockout mice models ${ }^{7}$. Autosomal dominant forms of hypodontia have been shown to be caused by mutations in the MSX1 and PAX9 genes in human families ${ }^{25}$. However, the origin of the isolated sporadic agenesis, the most common form of hypodontia in humans, is still unknown.
To date only a limited number of mutations of MSX1 and $P A X 9$ have been proven to be associated with severe hypodontia (oligodontia) in humans ${ }^{11}$.

$P A X 9$ is a transcription factor that is expressed in dental mesenchyme at initiation, bud, cap and bell stages of odontogenesis ${ }^{15}$. Protein products of this gene serve as transcription factors that are responsible for the crosstalk between epithelial and mesenchymal tissues and are essential for the establishment of the odontogenic potential of the mesenchyme ${ }^{23,27}$. It has been found that $P A X 9$-deficient mice lack teeth and pharyngeal pouches derivates and have severe craniofacial anomalies ${ }^{16}$. The expression of $P A X 9$ in the mesenchyme appears to be a marker for the sites of tooth formation as it occurs before any morphological manifestation of this process ${ }^{12}$. Mutations in this gene have been shown to be associated with autosomal dominant forms of oligodontia (agenesis of more than 6 teeth, MIM 604625) 
in humans ${ }^{10,25}$. In most families, mutations occur in exon 2 affecting the function of $P A X 9$ paired domain that is responsible for the binding of this protein to DNA target sequences. Affected individuals have severe tooth agenesis with absence of most molars, second premolars and some incisors. PAX9 is critical for the regulation of BMP4 expression through its paired domain rather than $M s x 1^{13}$.

Polymorphisms are a mechanism by which individuals may exhibit variations within the range of what is considered biologically normal. Gene polymorphisms have also been associated with susceptibility to diseases. Most polymorphisms are single nucleotide exchanges that occur at a high frequency in the human genome and may affect the function of genes. Although it has been demonstrated that mutations in the coding sequences of $P A X 9$ are a causative factor in familiar forms of severe tooth agenesis, polymorphisms in this gene have not been associated with sporadic tooth agenesis.

Previous studies have shown that two polymorphisms in the $P A X 9$ promoter region seem to be associated to the dental agenesis in human beings (G-1031A, T-912C T-160C). The purpose of the present study was to investigate whether the G-915C single nucleotide polymorphism (SNPs) in the $P A X 9$ gene promoter is associated with hypodontia in humans ${ }^{15,22}$.

\section{MATERIAL AND METHODS}

\section{Subject Selection and Sampling}

One hundred and thirty unrelated Caucasian individuals with hypodontia, without signs of other disorders and 110 healthy control individuals (without hypodontia) were interviewed and documented. Congenital absence of teeth was confirmed by X-ray examination. No other dental anomalies were observed in the subjects. The sampling of epithelial buccal cells was performed as previously described ${ }^{15}$. Briefly, individuals undertook a mouthwash of $5 \mathrm{~mL} \mathrm{3 \%}$ glucose. Following mouthwash, a sterile wooden spatula was used to scrape oral mucosa. The tip of the spatula was then shacked into the retained mouthwash solution. Buccal epithelial cells were pelleted by centrifugation at $2000 \mathrm{rpm}$ for $10 \mathrm{~min}$. The supernatant was discarded and the cell pellet resuspended in $500 \mu \mathrm{L}$ extraction buffer [10 mM Tris- $\mathrm{HCl}$ (pH 7.8), 5 mM EDTA, 0.5\% SDS]. The samples were then frozen at $-20^{\circ} \mathrm{C}$ until used for DNA extraction. After defrosted, samples were incubated overnight with $100 \mathrm{ng} / \mathrm{mL}$ proteinase K (Sigma Chemical Co., St. Louis, MO, USA) at $37^{\circ} \mathrm{C}$ with agitation. DNA was then purified by sequential phenol/chloroform extraction and salt/ethanol precipitation. DNA was dissolved in $70 \mu \mathrm{L}$ TE buffer [10 mM Tris (pH 7.8), 1 mM EDTA]. The concentration was estimated by measurements of OD $260^{15}$.

\section{Polymerase Chain Reaction (PCR)}

Amplification of the $P A X 9$ gene fragment was performed with the oligonucleotides 5'AGC CTG AAT CCT GTG TGC AC-3' (forward) and two reverses to amplify the region with alleles $\mathrm{G}$ or $\mathrm{C}$. To amplify the alelles $\mathrm{G}$ the oligonucleotide 5'GAA ATA TTT TCG TGA ATT TGG GAG'-3' was used and the $\mathrm{C}$ allele was amplified with the oligonucleotide 5'ATT TTC GTG AAT TTG GGAC'-3' (NCBI ref SNP ID: rs 2073245). Reactions were conducted in a total volume of 50 iL, containing: $10 \mathrm{mM}$ Tris- $\mathrm{HCl}(\mathrm{pH} 8.3), 50 \mathrm{mM} \mathrm{KCl}, 1 \mathrm{mM}$ of each primer, $200 \mathrm{mM}$ each dATP, dCTP, dGTP and dTTP, $25 \mathrm{mM} \mathrm{MgCl} 2$ and 2.5 units Taq DNA polymerase (Amersham Pharmacia Biotech, Uppsala, Sweden). The thermal cycling conditions consisted of an initial denaturation at $95^{\circ} \mathrm{C}$ for $5 \mathrm{~min}$ followed by 35 cycles of $95^{\circ} \mathrm{C}$ for $60 \mathrm{sec}$, annealing at $56^{\circ} \mathrm{C}$ for $70 \mathrm{sec}$, and a final extension at $72^{\circ} \mathrm{C}$ for $70 \mathrm{sec}$. Reactions were performed on a GeneAmp ${ }^{\circledR}$ PCR System 2400 thermocycler (Perkin Elmer).

PCR products of $P A X 9$ were submitted to $10 \%$ polyacrylamide gel electrophoresis and the DNA bands were labeled by silver staining ${ }^{15}$.

\section{Statistical Analysis}

The significance of the differences in observed frequencies of polymorphisms in both groups was assessed by odds-ratio and chi-squared test with $95 \%$ confidence interval. All statistical analysis was conducted using BioEstat program version 2.0. Differences were considered significant at $\mathrm{p}<0.05^{15}$.

\section{RESULTS}

The statistical analysis showed significant differences in the alleles and genotypes frequencies in the promoter polymorphisms of $P A X 9$ gene (G-915C). The $\mathrm{C}$ allele was found in $31.4 \%$ of the control group and in $42.5 \%$ of the test group (individuals with hypodontia) $(\mathrm{p}=0.0014)$. The $\mathrm{G} / \mathrm{G}$ and $\mathrm{C} / \mathrm{C}$ genotypes frequencies were $39.1 \%$ and $1.8 \%$ in the control group and $26 \%$ and $11.4 \%$ in the test group respectively ( $\mathrm{p}=0.0045)$. The frequencies of different alleles and genotypes of the $P A X 9$ gene are shown in Table 1 . The association was confirmed when the CC genotype is confronted with $\mathrm{CG} / \mathrm{GG}$. Individuals with $\mathrm{CC}$ genotype seemed to be seven times more susceptible to develop hypodontia $(\mathrm{OR}=7.04 ; 95 \% \mathrm{CI}=1.1-15.2 ; \mathrm{p}=0.0034)$.

\section{DISCUSSION}

The G-915C polymorphism in the 5' flanking region of $P A X 9$ gene could be associated with hypodontia in humans. $\mathrm{CC}$ genotype was found at a significant higher frequency in individuals with hypodontia. Analysis of human families shows a strong effect of $P A X 9$ mutations on third molar agenesis, whereas mutations in this gene have a weaker but fairly evident effect on the development of incisors and premolars. ${ }^{4-6,18-20,24,28}$. Three other polymorphic alleles (T$160 \mathrm{C}, \mathrm{G}-1031 \mathrm{~A}$ and T-912C) located close to the polymorphic region evaluated here were also associated with hypodontia in humans ${ }^{22}$.

Families bearing $P A X 9$ mutation had tooth agenesis as 
the only clinical sign. The relative lack of pleiotropy of mutations in $P A X 9$ and on other genes affecting the dental field would account for the common variation in the form and number of teeth observed in humans and other mammals ${ }^{2}$. This would allow genetic changes to affect the earlier phases of tooth development, without interfering significantly with the development of other organs ${ }^{16}$.

Experimental and theoretical approaches have stressed the importance of cis-regulatory DNA sequences that control the transcription of genes as the basic modular unit that determine the positional information in developing structures $^{3}$. The cis-regulatory sequences of many genes are organized into independent modules that regulate the transcription of specific tissues at specific times during development ${ }^{7}$. The regulatory modules are usually constituted of multiple binding sites for transcription factors that can be located near the transcription start site, or thousand of base pairs away ${ }^{1}$. Mutations within individual modules can enhance or repress gene transcription in a tissue specific manner, allowing a mutation to exert its effect on a few or even a single morphogenetic field ${ }^{7}$. A relevant fact is the relative lack of pleiotropic effects of $P A X 9$ gene mutations in humans. Families bearing $P A X 9$ mutation had tooth agenesis as the only clinical sign. The relative lack of pleiotropy of mutations in $P A X 9$ gene and on other genes affecting the dental area would account for the common variation in the form and number of teeth observed in humans and other mammals ${ }^{2}$. This would allow genetic changes to affect the earlier phases of tooth development, without interfering significantly with the development of other organs.

For example, the down-regulation of $M s x 1$ expression in $P A X 9$-deficient mice and decreased levels of $B m p 4$ expression in $P A X 9$ and $M s \times 1$ homozygous null mice indicate that the three genes act within the same signaling pathway. Although recent studies of human $P A X 9$ mutations have enabled structure-function correlations, the precise molecular mechanisms that contribute to tooth agenesis are poorly understood. The functional studies of a previously described mutation (L21P) in the amino-terminal

subdomain of the $P A X 9$ paired domain demonstrate impaired transcriptional activation of the Msx1 and Bmp4 promoters. It is likely that the proline cyclic side chain blocks the main chain nitrogen atom and chemically prevents it from forming a hydrogen bond ${ }^{13}$.

In humans, the changes in the number of teeth tend to occur in the reverse of the sequence that teeth are formed during development, which also characterizes the general pattern of tooth loss observed during the evolution of placental mammals ${ }^{17}$. Variations in tooth number may have represented an important factor in the diversification of mammalian species. Like hypodontia, most evolutionary changes in tooth number resulted from the loss of one or two elements, in most cases the last member of a tooth family. In this regard, the study of genetic polymorphisms in tooth agenesis is a specially suited model to understand the association of gene polymorphisms and changes in morphology. Teeth are serially homologous structures and the effects of gene variations on the development of these structures can be easily quantified ${ }^{8}$. Individuals with distinct polymorphic alleles may exhibit subtle and specific phenotypic variations in dental patterning. In this sense, association studies between gene polymorphisms and hypodontia as well as other mild malformations that reflect qualitative defects of embryogenesis ${ }^{14}$, may help understanding the molecular mechanisms responsible for the phenotypic variations that may occur in distinct human populations and ethnic groups.

The first mutation described in human $P A X 9$ gene was an insertion of an additional $\mathrm{G}$ within the paired box sequence at nucleotide 219 (219InsG) of exon 2 in a family with oligodontia. Since then eight additional mutations in the coding region of $P A X 9$ gene were reported being associated with oligodontia in humans ${ }^{8}$. Seven out of the

TABLE 1- Genotype and allele distribution of the G-915C polymorphism of PAX9 gene in the control and hypodontia (third molar) groups

\begin{tabular}{|c|c|c|c|c|}
\hline \multirow{2}{*}{$\frac{\text { G-915C }}{\text { Genotype }}$} & \multicolumn{2}{|c|}{ Control } & \multicolumn{2}{|c|}{ Third molar agenesis } \\
\hline & $\mathrm{n}$ & $\%$ & $\mathrm{n}$ & $\%$ \\
\hline GG & 43 & 39.1 & 34 & 26.2 \\
\hline GC & 65 & 59.1 & 81 & 62.4 \\
\hline $\mathrm{CC}$ & 2 & 1.8 & 15 & 11.5 \\
\hline $\mathrm{p}$ & & & & 0.0045 \\
\hline $\mathrm{CC}$ & 2 & 1.8 & 15 & 11.5 \\
\hline GG/GC & 108 & 98.2 & 115 & 88.5 \\
\hline $\mathrm{p}^{*}$ & & & & 0.0034 \\
\hline OR $(95 \% \mathrm{Cl})$ & & & & 7.04(1.1-15.2) \\
\hline Allele & $\mathrm{n}$ & $\%$ & $\mathrm{n}$ & $\%$ \\
\hline $\mathrm{G}$ & 151 & 68.6 & 150 & 57.5 \\
\hline C & 112 & 31.4 & 110 & 42.5 \\
\hline $\mathrm{p}$ & & & & 0.0014 \\
\hline
\end{tabular}

$p^{*}$ : chi-squared test. 
nine reported mutations were located in the paired domain at exon 2. Recently, it has been shown that the 219InsG frameshift mutation dramatically reduces DNA binding of the $P A X 9$ paired domain and supports the hypothesis that loss of DNA binding is the pathogenic mechanism by which the mutation causes oligodontia ${ }^{9}$. Although mutations in the coding sequences of PAX9 and MSX1 genes are a causative factor in familiar forms of oligodontia ${ }^{6}$, the genetic origin of the isolated sporadic agenesis, the most common form of hypodontia in humans, is still unknown. We report here that three other polymorphisms (T-160C, G-1031A and $\mathrm{T}-912 \mathrm{C})$ in the 5' flanking region of $P A X 9$ gene are associated with hypodontia in humans. Other alleles, such as $\mathrm{C}(-160)$, A (-1031) and C (-912) were found at a significant higher frequency in individuals with hypodontia. A comparative analysis of mouse, rat and human $P A X 9$ 5' flanking sequences shows that the $\mathrm{T}-160 \mathrm{C}$ is located in a poorly conserved region when human and rodent (mice and rat) sequences are compared. Although the present study showed a positive association on genotype and odds ratio, the results must be confirmed by studies with other populations and functional experiments, such as homologous recombination in mice, gel shift analysis and reporter gene systems.

\section{CONCLUSION}

The findings of this study showed that the allele $\mathrm{C}$ could be associated with third molar agenesis.

\section{REFERENCES}

1- Arnone MI, Davidson EH. The hardwiring of development: organization and function of genomic regulatory systems. Development. 1997;124:1851-64.

2- Bateson W. Materials for the study of variation, treated with special regard to discontinuity in the origin of species. London: Macmillan; 1894

3- Edelman GM, Gally JA. Degeneracy and complexity in biological systems. Proc Natl Acad Sci USA. 2001;98:13763-8.

4- Grainger DJ, Heathcote K, Chiano M, Snieder H, Kemp PR, Metcalfe JC, et al. Genetic control of the circulating concentration of transforming growth factor type beta1. Hum Mol Genet. 1999;8:93-7.

5- Grainger DJ, Metcalfe JC. Transforming growth factor-beta and cardiovascular protection. In: Rubanyi GM, Dzau VJ editors. The endothelium in clinical practice. source and target of novel therapies. New York: Marcel Dekker Inc; 1997. p. 203-43.

6- Hobbs K, Negri J, Klinnert M, Rosenwasser LJ, Borish L. Interleukin10 and transforming growth factor-beta promoter polymorphisms in allergies and asthma. Am J Respir Crit Care Med. 1998;158:195862

7- Line SRP. Molecular morphogenetic fields in the development of human dentition. J Theor Biol. 2001;211:67-75.
8- Line SRP. Variation of tooth number in mammalian dentition: connecting genetics, development and evolution. Evol Dev. $2003 ; 5: 295-304$

9- Mensah JK, Ogawa H, Kapadia H, Cavender AC, D'Souza RN. Functional analysis in a mutation in $P A X 9$ associated with familial tooth agenesis in humans. J Biol Chem. 2004;279:5924-33.

10- Mostowska A, Kobielak A, Trzeciak WH. Molecular basis of non-syndromic tooth agenesis: mutations of MSX1 and PAX9 reflect their role in patterning human dentition. Eur J Oral Sci. $2003 ; 111(5): 365-70$.

11- Mostowska A, Biedziak B, Trzeciak WH. A novel c.581C $>$ T transition localized in a highly conserved homeobox sequence of MSX1: is it responsible for oligodontia? J Appl Genet. 2006;47(2):159-64

12- Neubuser A, Peters H, Balling R, Martin GR. Antagonistic interactions between FGF and BMP signaling pathways: a mechanism for positioning the sites of tooth formation. Cell. 1997;90(2):24755

13 - Ogawa T, Kapadia H, Wang B, D’Souza RN. Studies on PAX9Msx1 protein interactions. Arch Oral Biol. 2005;50(2):141-5.

14- Opitz JM. Heterogeneity and minor anomalies. Am J Med Genet. 1999;91:254-5.

15- Peres RC, Line SR. Analysis of MMP-9 and TIMP-2 gene promoter polymorphisms in individuals with hypodontia. Braz Dent J. $2005 ; 16(3): 231-6$.

16- Peters H, Neubuser A, Kratochwil K, Balling R. PAX9-deficient mice lack pharyngeal pouch derivatives and teeth and exhibit craniofacial and limb abnormalities. Genes Dev. 1998;12(17):273547 .

17- Peyer B. Comparative odontology. Chicago: The University of Chicago Press; 1968.

18- Pulleyn LJ, Newton R, Adcock IM, Barnes PJ. TGF-beta 1 association with asthma severity. Hum Genet. 2001;109:623-7.

19- Rasmussen S, Rapraeger A. Altered structure of the hybrid cell surface proteoglycan of mammary epithelial cells in response to transforming factor-beta. J Cell Biol. 1988;107:1959-67.

20-Rizzino A. Transforming growth factor-beta: multiple effects on cell differentiation and extracellular matrices. Dev Biol. 1988;130:411-22.

21 - Ronshaugen M, McGinnis N, Inglis D, Chou D, Zhao J, McGinnis W. Structure and expression patterns of Drosophila TULP and TUSP, members of the tubby-like gene family. Mech Dev. 2002;117:20915

22-Saito CPB, Bianchi FJ, Peres RCR, Line SRP. Suggestive associations betwen polymorphisms in PAX9, MSX1 genes and thrid molar agenesis in humans. Curr Genomics. 2006;7:191-6.

23 - Scarel-Caminaga RM, Pasetto S, Silva ER, Peres RCR. Genes and tooth development: reviewing the structure and function of some key players. Braz J Oral Sci. 2003;7:339-47.

24- Shimo T, Wu C, Billings PC, Piddington R, Rosenbloom J, Pacifici $\mathrm{M}$, et al. Expression, gene regulation, and roles of Fisp12/CTGF in developing tooth germs. Dev Dyn. 2002;224:267-78.

25- Stockton DW, Das P, Goldenberg M, D'Souza RN, Patel PI. Mutation of $P A X 9$ is associated with oligodontia. Nat Genet. 2000;24:18-9. 
26- Thesleff I. Two genes for missing teeth. Nat Genet. 1996;13:379-

80

27 - Tucker AS, Sharpe P. Molecular genetics of tooth morphogenesis and patterning of the right shape in the right place. J Dent Res.1999;78:826-34.

28-Vaahtokari S, Vainio S, Thesleff I. Associations between transforming growth factor- beta1 RNA expression and epithelialmesenchymal interactions during tooth morphogenesis. Development. 1991;113:985-94.

29- Vastardis H. The genetics of human tooth agenesis: new discoveries for understanding dental anomalies. Am J Orthod Dentofacial Orthop. 2000;117:650-6. 